\title{
Comparative study on shelf life quality of Brine Salted Taki (Channa punctatus Bloch, 1793) and Shoal (Channa striatus Bloch, 1801) at Refrigerator Temperature $\left(4^{0} \mathrm{C}\right)$
}

\author{
Farzana Binte Farid ${ }^{1 *}$, Dr. Gulshan Ara Latifa ${ }^{1}$, Dr. Subhash Chandra \\ Chakraborty $^{2}$, Mosarrat Nabila Nahid ${ }^{1}$ and Mohajira Begum ${ }^{3}$ \\ ${ }^{I}$ Department of Zoology, University of Dhaka, Dhaka 1000, Bangladesh \\ ${ }^{2}$ Department of Fisheries Technology, Bangladesh Agricultural University, Mymensingh, Bangladesh \\ ${ }^{3}$ Institute of food Science and Technology, BCSIR, Dhaka-1205, Bangladesh.
}

\begin{abstract}
A clear understanding on the difference between qualities and shelf lives of brine salted taki and shoal fish product stored at refrigerator temperature $\left(4^{0} \mathrm{C}\right)$ has been assessed by analyzing physical changes such as color, texture, odor and visual appearance by acceptability technique and changes in chemical index of $T V B-N, p H$ and FFA value (quality parameters). In processed condition (after 7 days of ripening period in brine salting), values of TVB- $\mathrm{N}, \mathrm{pH}$ and FFA were $5.7 \mathrm{mg} \mathrm{N} / 100 \mathrm{~g}, 6.8$ and $2.6 \%$ in case of taki and $3.64 \mathrm{mg} \mathrm{N} / 100 \mathrm{~g}$, 6.5 and $1.8 \%$ in case of shoal fish respectively. TVB-N, $p H$ and FFA value increased significantly $(p<0.05)$ with time of storage period and between two brine salted products, TVB-N, $p H$ and FFA value rapidly increased in taki fish than shoal fish and at the end of 9 months brine salted taki fish product became spoiled whereas brine salted shoal fish still remained fresh. Experimentally it has been proved that brine salted shoal fish has longer shelf life (18 months) and is better to preserve in Refrigerator temperature $\left(4^{0} \mathrm{C}\right)$.
\end{abstract}

Key Words: Brine-Salting, Quality-analysis, Shoal, Shelf-life, Taki

\section{Introduction}

Fish represents an important source of food for mankind throughout the world and is a very important source of animal protein $[1,2,3,4]$. The important constituents of fish are water (70.0-85.0\%), protein (15.0$20.0 \%)$, lipid (1.0-10.0\%), ash (1.0-1.5\%) and carbohydrate $(0.3-1.0 \%)[4,5,6]$.

During the last decades in this century, healthy eating habits have received increased attention, and it is widely recognized that regular fish consumption is one possible health improving practice [7, 8].

Fish is also a very good source of vitamins and minerals [6,9]. Most noticeably, the high nutrient containing biochemical composition classified fish as highly perishable food.

An estimated $50 \%$ of the fish produced in the remote coastal settlements and hinterland perish before reaching the consumers, as a result of poor handling, preservation and processing and for this; the fish loses its organoleptic characteristics and becomes progressively more unacceptable for human consumption [10].

Most kinds of fishes are readily decomposed by microorganisms unless special methods are used for their preservation. Spoilage of fish not only occurs at room temperature but also at the refrigeration temperature $\left(4-7^{0} \mathrm{C}\right)$. The goals of fish preservation methods are to increase the shelf life of the food and ensure the safety for human consumption. There is various fish preservation methods include-Drying, salting, smoking, freezing, use of low temperature, high temperature, etc. Among them, salting of fish is probably one of the oldest methods of fish preservation. Brine-salting is one kind of salt curing method. It is well known that brine-salting is a process which aims to reach the saline equilibrium between fish muscle and the surrounding salt solution in a specific time [11]. Salting reduces water activity $\left(\mathrm{a}_{\mathrm{w}}\right)$ and inhibits the growth of many spoilage microorganisms and pathogen. In Bangladesh, India, Burma, Thailand and Sri Lanka salting of fish is popular. Different processing methods have different effects on the nutritional compositions of fish. This is because heating, freezing and exposure to high concentration of salt lead to chemical and physical changes and therefore digestibility is increased, due to protein denaturation, but the content of thermolabile compounds and polyunsaturated fatty acids is often reduced [12].

Therefore the quality of fish processed by the various methods cannot be the same and hence its subsequent effect on the fish's shelf life also varies.

Among the freshwater fish species Taki (C. punctatus) and Shoal (C. striatus) are very popular air-breating fish and also important due to commercial purpose. These fishes bear high market price and are delicious, nutritious and popular to the consumers. So it is necessary to take some steps for their proper preservation and marketing and during this period maintain proper quality.

* To whom communication should be made, e-mail: farzanafarid79@gmail.com 
The people of Bangladesh are habituated and preferred to take fish in fresh condition. But it is difficult to reach the fish in fresh condition to the consumers all over the season. More over the peak of snake-headed taki and shoal fish catch in Bangladesh is seasonal. During catching season, the catch is much higher than the consumers need. So these need to store and transport carefully and safely to keep in good, acceptable condition.

Due to high population growth there is an ever ending gap between supply and demand of fish and fisheries products in Bangladesh. Narrowing the gap not only requires increasing production but also improvement in all aspects of marketing and distribution system is also important [13]. For this the harvested fish and fisheries products should be processed properly to reduce the gap between supply and demand.

Quality assessments are necessary to ensure food safety of any processed products. Therefore in present study, analysis of different parameters was carried out to assess the qualities of brine-salted Taki and Shoal fish stored at refrigerator temperature.

\subsection{Collection of the fishes and location of the experiment:}

\section{Materials and Methods}

The fresh fish (Taki and Shoal) had been collected from the river Meghan in the early hours of the day and the fishes were brought to the Fish Technology Section, IFST, BCSIR, Dhaka for conducting the research activities, starts in the month of January, 2012.The whole experimental period covered 18 months of duration started from January, 2012 to July, 2013.

\subsection{Preparation of fish:}

The fishes were carefully washed with cooled tap water. Head, scales, fins, gills and viscera were removed and again washed with tap water to remove blood, slime and unnecessary flesh. Due to the presence of hard shield like bony elements, bones of head are discarded as waste.

\subsection{Fresh Sample:}

A few fresh fish-samples of Taki and Shoal fish species was taken to the laboratory for quality analysis. 6 or 7 slice was taken randomly which represented the parts from whole body of the fish. Then the slices were chopped with skin and finally ground with an electric blender to make a homogenous sample before being sampled for analysis.

\subsection{Brine salting (BS) method:}

Being a safe, antimicrobial and incidental food additive, toxic for some microorganisms, depressor of water activity $\left(\mathrm{a}^{\mathrm{w}}\right)$ of the food, sodium chloride has been used as a seasoning and flavor enhancer as well as a preservative or curing agent $[14,15,16]$.

During this experiment A 30\% salt solution is prepared (30 gm salts in $100 \mathrm{ml}$ water) which is called brine. The fishes are kept at this saturated brine solution stacked in containers and stored for a salting or curing period, at room temperature $\left(26^{\circ} \mathrm{C}-30^{\circ} \mathrm{C}\right)$ for the production of brine-salted fish. The fish in brine were kept immersed by putting a glass weight.

During brine-salting process moisture content decreased and salt content increased considerably during the first 6 to 7 days which is called ripening period.

\subsection{Storage of the product:}

At the end of the ripening period, brine-salted product of two fishes was packaging with plastic bag maintaining aseptic condition as far as possible and was stored at refrigeration temperature $\left(4^{0} \mathrm{C}\right)$. The preservation period of product is linked to the amount of salt added; therefore a straight proportion is present between the amount of salt used and the preservation period [17].

\subsection{Sampling Regime and Procedures:}

Evaluation of quality changes in brine salted Taki and Shoal fishes were carried out 3 month interval for refrigeration temperature $\left(4^{0} \mathrm{C}\right)$, until the fish become spoil or inedible condition. The experiment was done for second time at regular intervals during salting period.

There are some parameters which determine the quality of salted fish during storage condition, such asfreshness test by sensory scores, TVB-N value, pH, FFA etc. Freshness test of the fishes indicate the quality test in term of odor, color and appearance in different species. TVB-N value, $\mathrm{pH}$, FFA of fishes is important indicator to determine the quality of fish.

\subsection{Estimation of sensory score:}

Determination of the quality of Brine salted taki and shoal fish was made by trained panel of six judges in BCSIR, IFST Lab. following 9-point hedonic scales. Comparison was carried out in terms of sensory 
characteristics, such as color, flavor, texture and general appearance. The panel was requested to rate each sensory feature of the end products. The average score of 5 was considered to be the borderline of acceptability (9. Like extremely; 8. Like very much; 7. Like moderately; 6. Like slightly; < 5. Bad.) [18].

\subsection{TVB-N (Total Volatile Base Nitrogen) Estimation:}

TVB-N was determined by Conway modified micro-diffusion technique [19]. $25 \mathrm{ml}$ of $10 \%$ Trichloro Acetic Acid (TCA) was added to 2 gm of ground fish sample and kept overnight and then filtrated with known volume. $2 \%$ boric acid, $\mathrm{K}_{2} \mathrm{CO}_{3}$ and the solutions made from the fish samples were taken into the Conway dishes. After that, each dish was covered by a piece of glass that was stacked with glue (Paraffin soft white) initially. Then it was kept for 24 hours. The samples and Potassium Carbonate $\left(\mathrm{K}_{2} \mathrm{CO}_{3}\right)$ reacts to form $\mathrm{NH}_{3}$ which was absorbed by the boric acid and then the solution of each Conway dish had been titrated by $\mathrm{N} / 70 \mathrm{H}_{2} \mathrm{SO}_{4}$ with the help of a micro-burette.

Table: Showing the amount of chemicals taken in the inner and outer chamber of the Conway dishes:

\begin{tabular}{|c|l|c|l|c|}
\hline \multirow{2}{*}{$\begin{array}{c}\text { Conway } \\
\text { dishes }\end{array}$} & \multicolumn{2}{|c|}{ Chemical } & \multicolumn{2}{c|}{ Outer Chamber } \\
\cline { 2 - 5 } & \multicolumn{1}{|c|}{ Amount } & \multicolumn{1}{c|}{ Chemical } & $1 \mathrm{ml}$ \\
\hline Blank & $2 \%$ Boric acid & $1 \mathrm{ml}$ & $\mathrm{K}_{2} \mathrm{CO}_{3}$ & $1 \mathrm{ml}$ \\
\hline With Sample & $2 \%$ Boric acid & $1 \mathrm{ml}$ & Sample Solution & $1 \mathrm{ml}$ \\
\cline { 4 - 5 } & & & $\mathrm{K}_{2} \mathrm{CO}_{3}$ & \\
\hline
\end{tabular}

Finally TVB-N was calculated.

Calculation

$$
\text { TVB-N }=\text { (titration reading }- \text { blank reading }) \times \text { Strength of acid } \times 0.2 \times \frac{\text { Volume of extract }}{\text { Volume of extract taken }} \times \frac{100}{\text { Weight of sample taken }}
$$

\subsection{Estimation of $\mathrm{pH}$ :}

A $1 \mathrm{~g}$ sample of the fish flesh was homogenized in $10 \mathrm{ml}$ of distilled water and the mixture was filtered. The $\mathrm{pH}$ of the filtrate was measured using a pH meter (Mettler Toledo 320-s, Shanghi, China) [20].

\subsection{FFA (Free fatty acid) estimation:}

Oil sample used throughout the work was prepared by extracting the brine salted taki and shoal fish by Folch reagent (chloroform and methanol in the ratio of 2:1 v/v). The brine-salted fish was first cut into small pieces and then ground. The ground material was then mixed with folch reagent in a large wide mouthed stopper glass bottle for 24 hours at room temperature after 15 minutes stirring with glass rod. Extraction was facilitated by occasional shaking. The mixture was filtered through a Buchner funnel and the filtrate was evaporated in batches under heater or oven at $60^{\circ} \mathrm{C}$.

Seven gram of well-mixed oil was taken into $250 \mathrm{ml}$ flask and $50 \mathrm{ml}$ ethanol was added, previously neutralized by adding $2 \mathrm{ml}$ phenolphthalein solution. Titration was done by $0.25 \mathrm{~N}$ sodium hydroxide $(\mathrm{NaOH})$ with vigorous shaking until permanent final faint pink color appeared and persisted for at least one minute. The value was reported as percentage (\%) of free fatty acid expressed as oleic acid. Milli liter of $0.25 \mathrm{~N} \mathrm{NaOH}$ required for titration corresponds to the percentage of free fatty acid.

Data were analyzed by using SPSS for windows-20 statistical programme with five percent level of significance [21].

\section{Results and Discussion}

TVB-N, pH, FFA (Quality parameters) of fresh Taki fish was $3.43 \mathrm{mgN} / 100 \mathrm{~g}, 7.0 \& 0.5 \%$ and Shoal fish was $4.41 \mathrm{mgN} / 100 \mathrm{~g}, 6.9$ and $0.6 \%$ respectively (Fig. 1).

\subsection{Sensory evaluation (Score):}

According to the panel's evaluation, the sensory properties of Brine salted taki and shoal fish products were in acceptable condition throughout storage period though, statistically there was significant difference $(\mathrm{p}<0.05)$ in the sensory evaluation during storage period based on the panel's score (fig. 2). The initial score of the sensory evaluation of BS taki and shoal was 9. But during storage period this score rapidly decreased and at the end of the storage period, the score was 5 in case of BS taki ( 9 month) and BS shoal (18 month). This hedonic rating scale was applied to evaluate the acceptability of the sun dried fishes by their external morphological and quality changes [22]. This hedonic rating scale was also applied by using 9- points for the sensory evaluation of the dried and dehydrated fish [23]. 


\subsection{Changes in TVB-N value during storage period:}

TVB-N has been used as an index for the determination of freshness of fish [24, 25]. Volatile nitrogenous bases increase in concentration during the spoilage of fish [26].

Samples that were in the different levels of acceptability from highly acceptable condition to unacceptable condition had been selected for TVB-N analysis. Gram opined that, the level of TVB-N in fish \& fish products are mostly used as spoilage indicator through bacterial activity, the same result have been evident in the present study [27].

TVB-N values were found to vary from 5.70 (o day) to $24.48 \mathrm{mg} \mathrm{N} / 100 \mathrm{~g}$ (9 month) for BS Taki and 3.64 (o day) to $21.14 \mathrm{mg} \mathrm{N} / 100 \mathrm{~g}$ (18 month) for BS Shoal. Significant statistical differences were found between the initial product and end product $(\mathrm{P}<0.05)$ after storage period (fig. 3). TVB-N values of the products storage at refrigeration temperature showed linearly increasing pattern throughout storage period but neither of the value exceeded the recommended value set for fish regarded as acceptable condition. According to Connell the limiting level for rejection of TVB-N is $30-40 \mathrm{mgN} / 100 \mathrm{~g}$ for storage at ambient temperature and $20 \mathrm{mgN} / 100 \mathrm{~g}$ for storage at refrigerator temperature [28]. The present findings are in close association with him. The rate of spoilage increases with the time and is closely interrelated. The same result had been evident from several researchers $[29,30]$. The stage perhaps due to autolysis in the tissue [31].

\subsection{Changes in $\mathrm{pH}$ value:}

$\mathrm{pH}$ is an indicator of the extent of microbial spoilage in fish and some proteolytic microbes produce acid after decomposition of carbohydrate, thereby increasing the acid level of the medium. The $\mathrm{pH}$ value is a reliable indicator of the degree of freshness or spoilage [32].

The $\mathrm{pH}$ in fresh condition freshwater fish flesh is almost neutral [33]. In the post-mortem period, decomposition of nitrogenous compounds leads to an increase in $\mathrm{pH}$ in the fish flesh [34]. The increase in $\mathrm{pH}$ indicates the loss of quality. The $\mathrm{pH}$ value of BS taki and shoal fish-product was increased significantly $(\mathrm{P}<0.05)$ with storage period. $\mathrm{pH}$ value of fresh Taki and Shoal fish were found 7.0 and 6.9 respectively in the present study. But when salt was added with fish, $\mathrm{pH}$ value decreases rapidly while in the study of shelf life it was evident that the $\mathrm{pH}$ value increases with time. In the present study $\mathrm{pH}$ value were found to vary from 6.8 ( 0 day) to 7.8 (9 month) for BS Taki and 6.5 (0 day) to 7.2 (18 month) for BS Shoal (Fig. 4). The fish products are acceptable up to a $\mathrm{pH}$ of 6.8 but are considered to be spoiled above a $\mathrm{pH}$ of 7.0 [25]. This was similar to the present findings. The limit of acceptability is usually 6.8 to 7.0 [35].

\subsection{Changes in FFA value:}

Among the various parameters to assess the extent of deterioration in fish, determination of free fatty acid (FFA) content has been widely used. FFA a tertiary product of rancidity, increased during storage. The FFA is a measure of hydrolytic rancidity-the extent of lipid hydrolysis by lipase action. In most fish oils, rancidity is noticeable when the FFA (calculated as oleic acid) is in between 0.5\%-1.5\% [32]. It produced as a result of fat oxidation (rancidity). FFA value is a measure of the extent of oxidative deterioration in oily fish, but it can fall further at latter stages of fish spoilage [36]. A high level of FFA is characteristics of product that have undergone both microbial and biochemical spoilage [37].This may indicate that greater proportions of unsaturated fatty acids were liberated and were subjected to oxidative splitting at the double bonds. The resulting substances, mostly ketones and aldehydes, appear to be largely responsible for flavor, odor and taste of the salted fish product [38]. The same result was found in the present study.

The FFA value of salted shoal increased gradually with the passing of storage period (Fig. 5). Significant statistical differences were found between the initial product and end product $(\mathrm{P}<0.05)$ during storage period and it was vary from $2.6 \%$ (o day) to $12.8 \%$ (9 month) for BS Taki and $1.8 \%$ (o day) to $12.2 \%$ (18 month) for BS Shoal respectively. After 6 and 24 months of storage (at- $13^{0} \mathrm{C}$ to $-25^{\circ} \mathrm{C}$ ) the appearance of considerable contents of FFA with certain bad odors and off flavors presumably derived from the degradation of fats, greatly reduced the consumer appeal of trout [39]. Free fatty acid (FFA) value ranged from $2.9 \%$ of total lipid on the start day to $7.58,7.15$ and $8.56 \%$ on the 60 days of observation in dry salting, wet salting and sundry salted fishes respectively [40]. The initial value of raw pre-spawning and post-spawning hilsa was $1.15 \%$ and $1.21 \%$ respectively which after dry salting increased to $7.86 \%$ and $8.35 \%$ respectively on $18^{\text {th }}$ days of storage at $28^{0} \mathrm{C}$ to $32^{0} \mathrm{C}$ [41]. FFA contents increased from $4.55-5.12 \%$ within 4 days of drying and then gradually increased up to 10 days of drying $(6.86 \%)$ [42].

The present study denoted that the contents of free fatty acid values are similar with the above mentioned studies. The FFA value increased in a characteristics pattern to a certain level of storage period. 


\section{Conclusion}

From the present study, it was evident that, the quality analysis of the Brine salted Shoal has longer shelf life than Brine salted taki storage at refrigerator temperature $\left(4^{\circ} \mathrm{C}\right)$. The wide range of storage period indicates the diversity in the final quality and can be largely attributed to the effect of various conditions upon the salting agents and activities. It is seen that the main factor affecting the quality is time of storage and storage condition.

\section{Acknowledgement}

The author acknowledges the scientists and technicians of Fish technology laboratory, IFST, BCSIR, Dhaka, Bangladesh for their technical supports and continuous assistance to carry out the present study.

\section{References}

[1] Ravichandran, S. Kumaravel, K. Rameshkumar, G. and Ajithkumar, T. T. 2010. Antimicrobial peptides from the marine fishes. Res. J. Immunol., 3: 146-156.

[2] Ojewola, G.S. and Annah, S.I. 2006. Nutritive and economic value of Danish fish meal, crayfish dust meal and shrimp waste meal inclusion in broiler diets. Int. J. Poult. Sci., 5: 390-394.

[3] Chowdhury, M.H. and K.L. Maharjan, 2001. Pond fish production through people's participation in rural Bangladesh. J. Int. Dev. Cooperat. : 11-28.

[4] Sutharshing, S. and Sivashanthini, K. 2011. Total lipid and cholesterol content in the flesh of the five important commercial fishes from waters around Jafffna Peninsula, Sri Lanka. Int. J. Biol. Chem., 6: 161-169.

[5] Panuncio, A. 2001. Study report for the course on handling and processing of marine product: Surimi and surimi products. Bull. Fish. Res. Inst., 22: 2-11.

[6] Moghaddam, H. N. Mesgaran, M. D. Najafabadi, H. J. and Najafabadi, R. J. 2007. Determination of chemical composition, mineral contents and protein quality of Iranian Kilka fish meal. Int. J. Poultt. Sci., 6:354-361.

[7] Hoge Gezondheidsraad, 2004.Vis en gezondheidbijvolwassenen (Fish and health among adults). Report D/2004/7795/3. Brussels: FOD Volksgezondheid.

[8] Sidhu, KS, 2003. Health benefits and potential risks related to consumption of fish or fish oil. Regulations in Toxicology and Pharmacology, 38, 336-34.

[9] Edem, D.O. 2009. Vitamin A: A review. Asian J. Clin. Nutr.1: 65-82

[10] Eyo, A. A. 1997. Post Harvest Losses in the Fisheries of Kainji Lake. Nigerian-German Kainji Lake Fisheries Promotion Project Technical Report Series, 5: 75 pp.

[11] Zugarramurdi, A. and Lupin, H.M. 1980. A model to explain observed behavior on fish salting. J.Food Sci., 45(5): 1305-1311.

[12] Chukwu, O. and Shaba, I. M. 2009. Effects of Drying Methods on Proximate Compositions of Catfish (Clarias gariepinus) World J. of Agric. Sci. 5 (1): 114-116.

[13] ICLARM, 1991. Socio-economic impacts of fish culture extention programme. Annual Program Report, ICLARM, Dhaka.

[14] Klaassen, C.D. Amdur, M.O. and Doull, J.A. 1986. Principles of Toxicology. In: Casarett and Doull's Toxicology: The Basic Science of Poisons. New York: Macmillan.

[15] Leroi, F. Joffraud, J. J. and Chevalier, F. 2000. Effect of salt and smoke on the microbiological quality of cold- smoked salmon during storage at 5 Degrees $\mathrm{C}$ as estimated by the factorial design method. J. Food Prot. 63: 502-508.

[16] Turan, H. Sonmez, G. Celic, M.Y. \& Yalcin, M. 2007. Effects of different salting process on the storage quality of Mediterranean Muscle (Mystus Galloprovincialis L. 1819) J. Muscle Foods, 18: 380-390.

[17] Bahri, P. Ayse, G.I. Gulsum, O. and Irfan, I. 2006. Microbiological and chemical qualities of salted grey mullet. Int. J. Sci. Techno.2: 91-98.

[18] Peryan, D. R. Pilgrim, F. J. 1957. The Methodology of sensory testing, IFST sykp. Pittsburg, U.S.A. Food Technology Champaign II. 9-14.

[19] Conway, E. J. and Byrne, A. 1933. Micro-diffusion analysis of TVN. Biochem. J. 27:419-429.

[20] Vyncke, W. 1981. pH of fish muscle comparison of methods, Western European Fish Technologists' Association (WEFTA), Copenhagen, Denmark.

[21] Sokal R. R. and Rohlf F. J.,1962. Introduction to biostatistics. New York: W. H. Freeman and Company, 1987, 363pp

[22] Yu SY.1985. Comparison on sun-dried and oven dried salted fish. FAO Fish Rep. Supple: 317:328-330.

[23] Morshed M. 2005. Sun dried products of Bombay duck and its quality assessment at different storage condition. Department of Zoology, University of Dhaka. 29.

[24] Stansby, M.E. Harrison, R.W. Dassow, J. and Sater, M. 1944. Ind. Eng. Chem. Analyst, Edn.16 (9): 593 pp.

[25] Huss, H.H. 1988. Fresh Fish-quality and quality changes, FAO Fish. Series 29, FAO DANINAQ, Rome. Italy. 132 pp.

[26] Vynke, W. and Marlevede, E. 1963. Arch.Beges.Med. Ttavais.Med. Legale.21 (3):147-160.

[27] Gram, L. Ravn, L. Rasch, M. Bruhn, J.B. Christensen, A.B. and Givskov, M. 2002. Food spoilage-interactions between food spoilage bacteria. Inter. J. Food Microbiol.. 78: 79-97.

[28] Connell, J.J. 1995. Control of fish quality. Fourth edition published by fishing Books, a division of Blackwell Scientific Ltd.

[29] Reed, G. B. Rice, E.E. and Sinclair, R. J. 1929. Comparative study of analysis and bacterial decomposition in haddock, Lobster and Clamb muscle. cntribs. can. Bi. Fisheries. 4(18): 229-235.

[30] Muslemuddin, M. 1970. Some aspects of the determination of fish muscle during storage. A Department of Food. Sci. National College of Food. Tech. Uni. of Food. Technology. 84 pp.

[31] Tomiyasu, Y. and Zenitani, B. 1957. Spoilage of fish and its preservation by chemical agents, Advances in food Research Academic Press inc. M.Y and London. 7:42-74.

[32] Eyo, A.A. 1993. Traditional and improved fish handling, preservation and processing techniques. Paper presented at national workshop on fish processing storage, marketing and utilization.

[33] Virta, S. 2009. Bachelor's Thesis, Isolation and Identification of Rainbow Trout spoiling Microbiota. Biotechnology and Food Technology, Turku University of Applied Science. 8 pp. (Unpublished)

[34] Shenderyuk, V.I. and.Bykowski, P.J. 1989). Salting and Marinating of fish. In: Seafood Resources. Nutritional Composition and preservation, Sikorski, Z.E. (Ed.) CRC Press Inc. Boca Raton, Florida.

[35] Erkan, N. Tosun, S.Y. Ulusoy, S. Uretener, G. 2011. The use of thyme and laurel essential oil treatments to extend the shelf life of 
bluefish (Pomatomus saltatrix) during storage in Ice. Journal für Verbraucherschutz und Lebensmittelsicherheit 6(1): 39-48

[36] FAO/SIFAR, 2001. Non-Sensory Assessment of Fish Quality. (FAO in partnership with support unit for international Fisheries and Aquatic Research, SIFAR, Torry Advisory Note No. 92 pp.

[37] Horner, W.F.A. 1997. Preservation of fish by curing (drying, salting and smoking). In Fish Processing Technology. Blackie Academic

\& Professionals, New York .31-71.

[38] El-Sebahy, L. and Metwali, M. 1988. Changes in some Chemical Characteristics and Lipid Composition of salted Fermented Bouri fish Muscle (Mugil cephalus). Food Chem. 31: 41-50.

[39] Ranke, B. 1959. Arch. Fish creiwissen, 10: 117 pp.

[40] Chakraborty, S.C. Islam, M.N. and Khan, A.S. 1997. Study on the evaluation of the quality aspects of dry salted, wet salted and sun dried Hilsa fish (Hilsa ilisha). Bangladesh J. Agri. Sci. 24(2): 71-79.

[41] Mansur, M. N. Chakraborty, S.C. Uddin, M. N. and Khan, M. N. A. 1998. Influence of spawning on the sensory, biochemical and bacteriological characteristics of dry salted hilsa (Hilsa ilisha) fish at ambient temperature. Bangladesh J. Fish. 21 (1): 65-72.

[42] Azad Shah, A.K.M., C. Tokunaga, H. Kurihara and K. Takahashi, 2009. Changes in lipids and their contribution to the taste of migaki-nishin (dried herring fillet) during drying. Food Chem., 115: 1011-1018.

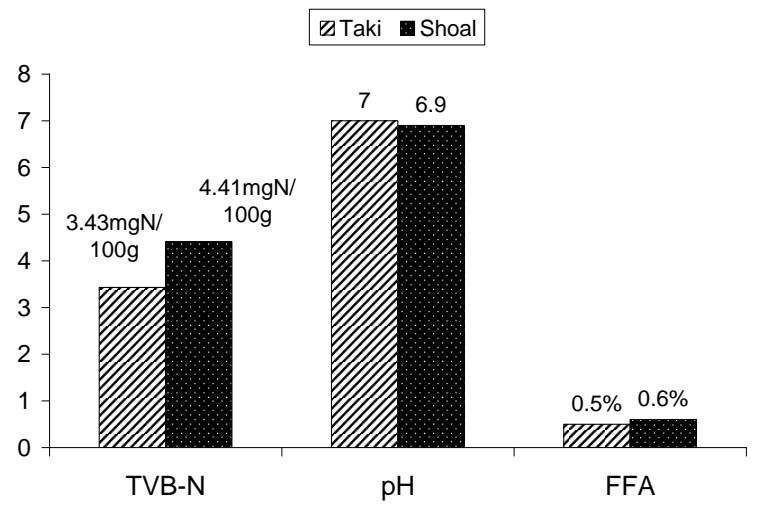

Figure 1. Initial quality of the fresh experimental fish, Taki (Channa punctatus) and Shoal (Channa striatus).

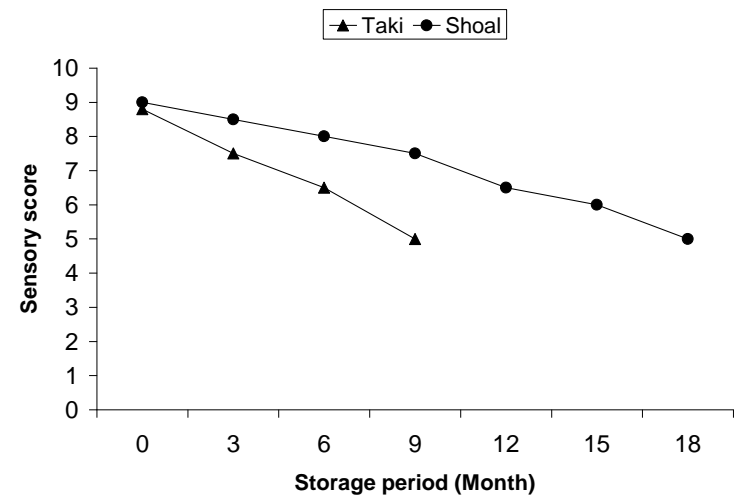

Figure 2. Changes in sensory score of brine salted Taki and Shoal fish during different duration of storage at Refrigerator Temperature.

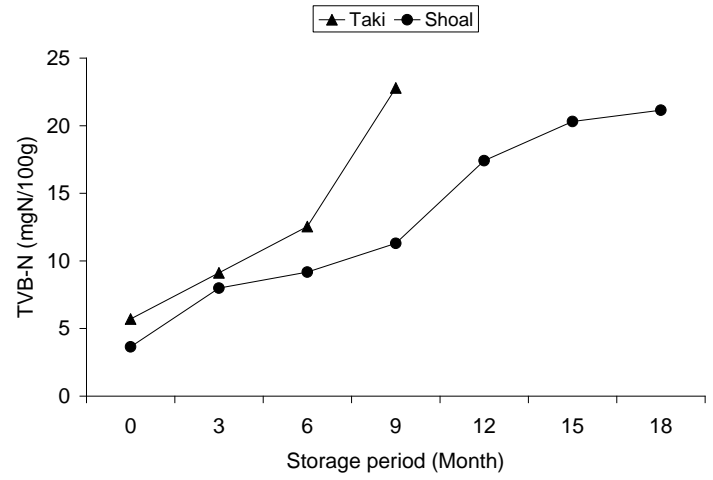

Figure 3. Changes in TVB-N (mgN/100g) contents of brine salted Taki and Shoal fish during different duration of storage at Refrigerator Temperature. 


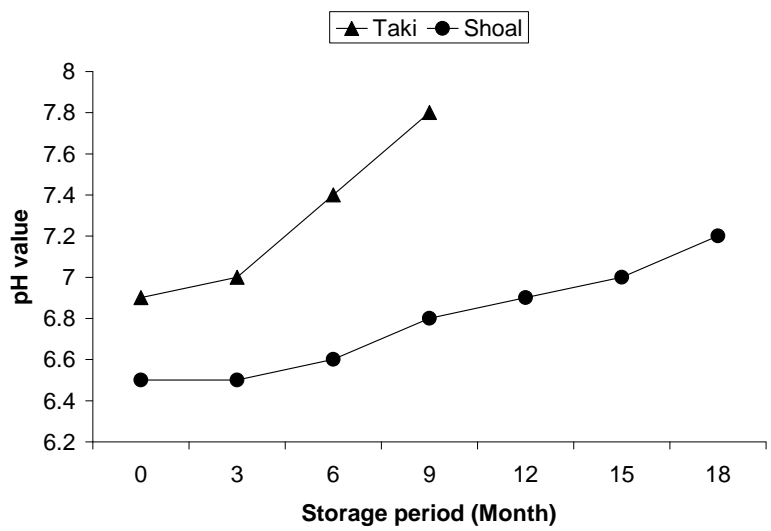

Figure 4. Changes in pH value of brine salted Taki and Shoal fish during different duration of storage at Refrigerator Temperature.

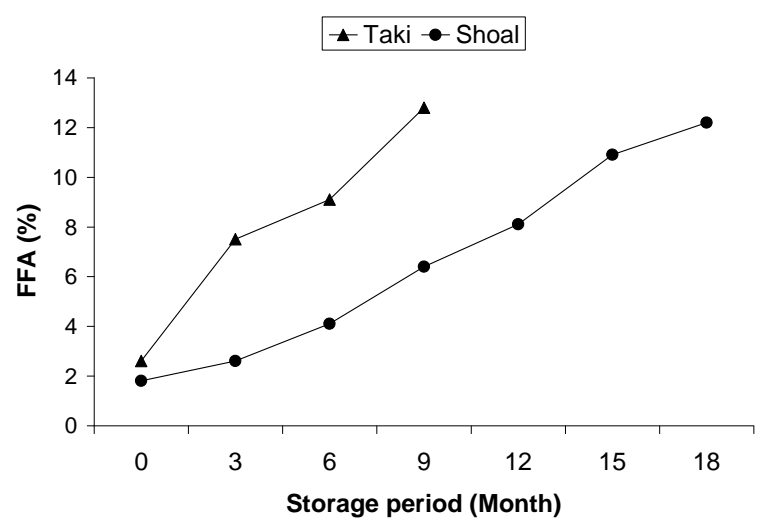

Figure 5. Changes in FFA (\%) value of brine salted Taki and Shoal fish during different duration of storage at Refrigerator Temperature. 